
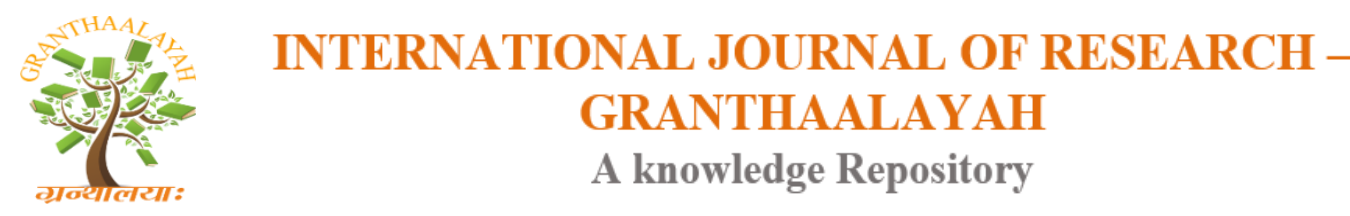

Science

\title{
REAL POWER LOSS REDUCTION BY ENHANCED ACCLIMATIZED BACTERIAL EXPLORATION ALGORITHM
}

\author{
Dr.K.Lenin ${ }^{* 1}$ \\ ${ }^{* 1}$ Professor, Department of EEE, Prasad V.Potluri Siddhartha Institute of Technology, Kanuru, \\ Vijayawada, Andhra Pradesh -520007, India
}

\begin{abstract}
This paper presents Enhanced Acclimatized Bacterial Exploration (EBE) algorithm to solve reactive power problem. Bacterial Search Optimization Algorithm has recently emerged as a very powerful technique based on the behaviour of E-coli bacteria. In order to speed up the convergence of Bacterial search Optimization Algorithm, this paper proposed a new hybridization between Bacterial Search Optimization Algorithm (BSO) and Particle Swarm Optimization (PSO). In order to evaluate the proposed Enhanced Acclimatized Bacterial Exploration (EBE) algorithm, it has been tested in standard IEEE 118 \& practical 191 bus test systems and compared to other standard algorithms.
\end{abstract}

Keywords: Enhanced Acclimatized Bacterial Exploration Algorithm; Particle Swarm Optimization; Optimal Reactive Power; Transmission Loss.

Cite This Article: Dr.K.Lenin. (2018). "REAL POWER LOSS REDUCTION BY ENHANCED ACCLIMATIZED BACTERIAL EXPLORATION ALGORITHM." International Journal of Research - Granthaalayah, 6(3), 182-190. 10.29121/granthaalayah.v6.i3.2018.1513.

\section{Introduction}

Various mathematical techniques have been adopted to solve this optimal reactive power dispatch problem. These include the gradient method [1, 2], Newton method [3] and linear programming [4-7].The gradient and Newton methods suffer from the difficulty in handling inequality constraints. To apply linear programming, the input- output function is to be expressed as a set of linear functions which may lead to loss of accuracy. Recently Global Optimization techniques such as genetic algorithms have been proposed to solve the reactive power flow problem [8.9]. In recent years, the problem of voltage stability and voltage collapse has become a major concern in power system planning and operation. To enhance the voltage stability, voltage magnitudes alone will not be a reliable indicator of how far an operating point is from the collapse point [10]. This paper presents Enhanced Acclimatized Bacterial Exploration (EBE) algorithm to solve reactive power problem. Bacterial Search Optimization Algorithm has recently emerged as a very powerful technique based on the behaviour of E-coli bacteria. In order to speed up the convergence of Bacterial search Optimization Algorithm, this paper 
proposed a new hybridization between Bacterial Search Optimization Algorithm (BSO) [11] and Particle Swarm Optimization (PSO) [12]. In order to evaluate the proposed Enhanced Acclimatized Bacterial Exploration (EBE) algorithm, it has been tested in standard IEEE 118 \& practical 191 bus test systems and compared to other standard algorithms.

\section{Problem Formulation}

The OPF problem is considered as a general minimization problem with constraints, and can be written in the following form:

Minimize $\mathrm{f}(\mathrm{x}, \mathrm{u})$

Subject to $g(x, u)=0$

And

$\mathrm{h}(\mathrm{x}, \mathrm{u}) \leq 0$

Where $f(x, u)$ is the objective function. $g(x . u)$ and $h(x, u)$ are respectively the set of equality and inequality constraints. $\mathrm{x}$ is the vector of state variables, and $\mathrm{u}$ is the vector of control variables.

The state variables are the load buses (PQ buses) voltages, angles, the generator reactive powers and the slack active generator power:

$\mathrm{x}=\left(\mathrm{P}_{\mathrm{g} 1}, \theta_{2}, \ldots, \theta_{\mathrm{N}}, \mathrm{V}_{\mathrm{L} 1}, ., \mathrm{V}_{\mathrm{LNL}}, \mathrm{Q}_{\mathrm{g} 1}, \ldots, \mathrm{Q}_{\mathrm{gng}}\right)^{\mathrm{T}}$

The control variables are the generator bus voltages, the shunt capacitors/reactors and the transformers tap-settings:

$\mathrm{u}=\left(\mathrm{V}_{\mathrm{g}}, \mathrm{T}, \mathrm{Q}_{\mathrm{c}}\right)^{\mathrm{T}}$

Or

$\mathrm{u}=\left(\mathrm{V}_{\mathrm{g} 1}, \ldots, \mathrm{V}_{\mathrm{gng}}, \mathrm{T}_{1}, \ldots, \mathrm{T}_{\mathrm{Nt}}, \mathrm{Q}_{\mathrm{c} 1}, \ldots, \mathrm{Q}_{\mathrm{cNc}}\right)^{\mathrm{T}}$

Where $\mathrm{Ng}, \mathrm{Nt}$ and $\mathrm{Nc}$ are the number of generators, number of tap transformers and the number of shunt compensators respectively.

\section{Objective Function}

\subsection{Active Power Loss}

The objective of the reactive power dispatch is to minimize the active power loss in the transmission network, which can be described as follows: 
$F=P L=\sum_{k \in N b r} g_{k}\left(V_{i}^{2}+V_{j}^{2}-2 V_{i} V_{j} \cos \theta_{i j}\right)$

Or

$F=P L=\sum_{i \in N g} P_{g i}-P_{d}=P_{\text {gslack }}+\sum_{i \neq s l a c k}^{N g} P_{g i}-P_{d}$

Where $g_{k}$ : is the conductance of branch between nodes $i$ and $j$, Nbr: is the total number of transmission lines in power systems. $\mathrm{P}_{\mathrm{d}}$ : is the total active power demand, $\mathrm{P}_{\mathrm{gi}}$ : is the generator active power of unit $\mathrm{i}$, and $\mathrm{P}_{\text {gsalck: }}$ is the generator active power of slack bus.

\subsection{Voltage Profile Improvement}

For minimizing the voltage deviation in PQ buses, the objective function becomes:

$F=P L+\omega_{v} \times V D$

Where $\omega_{\mathrm{v}}$ : is a weighting factor of voltage deviation.

VD is the voltage deviation given by:

$V D=\sum_{i=1}^{N p q}\left|V_{i}-1\right|$

\subsection{Equality Constraint}

The equality constraint $\mathrm{g}(\mathrm{x}, \mathrm{u})$ of the ORPD problem is represented by the power balance equation, where the total power generation must cover the total power demand and the power losses:

$P_{G}=P_{D}+P_{L}$

This equation is solved by running Newton Raphson load flow method, by calculating the active power of slack bus to determine active power loss.

\subsection{Inequality Constraints}

The inequality constraints $\mathrm{h}(\mathrm{x}, \mathrm{u})$ reflect the limits on components in the power system as well as the limits created to ensure system security. Upper and lower bounds on the active power of slack bus, and reactive power of generators:

$P_{\text {gslack }}^{\min } \leq P_{\text {gslack }} \leq P_{\text {gslack }}^{\max }$

$Q_{g i}^{\min } \leq Q_{g i} \leq Q_{g i}^{\max }, i \in N_{g}$

Upper and lower bounds on the bus voltage magnitudes: 
$V_{i}^{\min } \leq V_{i} \leq V_{i}^{\max }, i \in N$

Upper and lower bounds on the transformers tap ratios:

$T_{i}^{\min } \leq T_{i} \leq T_{i}^{\max }, i \in N_{T}$

Upper and lower bounds on the compensators reactive powers:

$Q_{c}^{\min } \leq Q_{c} \leq Q_{C}^{\max }, i \in N_{C}$

Where $\mathrm{N}$ is the total number of buses, $\mathrm{N}_{\mathrm{T}}$ is the total number of Transformers; $\mathrm{N}_{\mathrm{c}}$ is the total number of shunt reactive compensators.

\section{Bacterial Search Optimization Algorithm}

Bacterial Search Optimization Algorithm (BSO) is based on foraging behaviour of Escherichia coli (E.coli) bacteria present in the human intestine and been already implemented to real world problems [13]. In this foraging theory, the objective of the animal is to search for and obtain nutrients in a fashion that energy intake per unit time $(E / T)$ is minimized [11]. A group of bacteria move in search of food and away from noxious elements known as Foraging. BSO algorithm draws its inspiration from this foraging behaviour. Bacteria have a tendency to gather to the nutrient-rich areas by activity called Chemo taxis. Its movement and behaviour is characterized by the spinning flagella which acts as a Biological motor and helps bacteria to swim. An e.coli bacterium has 8-10 flagella placed randomly on its body with a speed of 100$200 \mathrm{rps}$. An E.coli bacteria alternate through running and sinking. Running speed is $10-20 \mathrm{~m}=\mathrm{s}$ and they cannot swim straight. The flagella can rotate either clockwise or counter clockwise. When all the flagella rotate counter clockwise, they form a compact, helically propelling the cell along a trajectory, which is called "run". When the flagella rotate in clockwise direction they enable the bacterium to move in different directions and cause bacteria to "tumble". The bacterial foraging process consists mainly of four sequential mechanisms namely chemo taxis, swarming and reproduction and elimination-dispersal.

\subsection{Chemo Taxis}

An E.coli bacterium can move in two different ways: it can run (swim for a period of time) or tumble and alternates between these movements throughout its travel in search of food. In BSO, a unit walk with random direction represents a "tumble" and a unit walk with the same direction in the last step indicates "run". In the computational chemo taxis, the movement of $i^{\text {th }}$ bacterium after one step can be represented as

$\theta^{i}(j+1, k, l)=\theta^{i}(j, k, l)+C(i) \varphi(j)$

Here $\theta^{i}(j, k, l)$ denotes the location of $\mathrm{i}^{\text {th }}$ bacterium at $\mathrm{j}^{\text {th }}$ chemo tactic $\mathrm{k}^{\text {th }}$ reproductive and $\mathrm{l}^{\text {th }}$ elimination and dispersal step. C(i) is the length of unit walk, which is constant in basic BFO and $\varphi(j)$ is the direction angle of the $\mathrm{j}^{\text {th }}$ step. When the bacterium is in run mode $\varphi(j)$ is same as $\varphi(j-1)$, otherwise $\varphi(j)$ is a random angle directed within a range of $[0,2 \Pi]$. If the cost 
at $\theta^{i}(j+1, k, l)$ is better than the cost at $\theta^{i}(j, k, l)$, then the bacterium takes another step of size $\mathrm{C}(\mathrm{i})$ in that direction otherwise it is allowed to tumble. This process is repeated until the number of steps taken is greater than the number of iterations in chemo tactic loop, $\mathrm{N}_{\mathrm{c}}$

\subsection{Swarming}

A bacterium in times of stresses releases attractants to signal the bacteria to swarm together. Each bacterium also releases repellent to signal the others to be at a minimum distance from it. Thus all of them will have a cell to cell attraction via attractant and cell to cell repulsion via repellent. The cell to cell signalling in E.coli swarm may be mathematically represented as

$j_{c c}(\theta, P(j, k, l))=\sum_{i=1}^{s} j_{c c}\left(\theta, \theta^{i}(j, k, l)\right)=\sum_{i=1}^{s}\left[-d_{\text {attractant }} \exp \left(-\delta_{\text {attractant }} \sum_{m=1}^{p}\left(\theta_{m}-\right.\right.\right.$ $\left.\left.\left.\theta_{m}^{i}\right)^{2}\right)\right]+\sum_{i=1}^{s}\left[h_{\text {repellent }} \exp \left(-\delta_{\text {repellent }} \sum_{m=1}^{p}\left(\theta_{m}-\theta_{m}^{i}\right)^{2}\right)\right]$

Here $j_{c c}(\theta, P(j, k, l))$ represents objective function value to be added to actual objective function, $\mathrm{S}$ is the total number of bacteria, $\mathrm{P}$ is the number of parameters to be optimized and $\theta=\left[\theta_{1}, \theta_{2}, \ldots, \theta_{P}\right]^{T}$ is a point in p-dimensional search domain. $\mathrm{d}_{\text {attractant }}$ is the depth of attractant released by the cell and $\delta_{\text {attractant }}$ is the measure of width of the attractant signal. $\mathrm{h}_{\text {repellent }}=\mathrm{d}_{\text {attractant }}$ is the height of repellant effect magnitude, $\delta_{\text {repellent }}$ is a measure of width of repellant. These coefficients are to be taken judiciously.

\subsection{Reproduction}

After the completion of all $\mathrm{N}_{\mathrm{c}}$ chemo tactic steps a reproduction step takes place. Fitness value of the bacteria is stored in ascending order. The lower half of bacteria having a higher fitness die and remaining $S_{r}=S / 2$ bacteria are allowed to split into two identical one. Thus the population after reproduction remains constant.

\subsection{Elimination and Dispersal}

There is a probability that bacteria may be stuck around the initial or local optima positions, it is required to diversify the bacteria either gradually or suddenly so that the possibility of being trapped in to local minima is eliminated and global optima is obtained. The dispersion operation takes place after a certain number of reproduction processes. A bacterium is chosen, according to a present probability $p_{\text {ed }}$, to be dispersed and moved to another position within the environment. This may disturb optimization process but prevent the local minima trapping.

\section{Enhanced Acclimatized Bacterial Exploration (EBE) Algorithm}

This paper presents Enhanced Acclimatized Bacterial Exploration (EBE) algorithm to solve reactive power. In order to speed up the convergence of Bacterial search Optimization Algorithm (BSO), this paper proposed a new hybridization between Bacterial Search Optimization Algorithm (BSO) and Particle Swarm Optimization (PSO). The aim is to make PSO ability to exchange social information and BSO ability in finding new solution by elimination and dispersal, a unit length direction of tumble behaviour is randomly generated. Random direction 
may lead to delay in reaching the global solution. In EBE algorithm the unit length random direction of tumble behaviour can be decided by the global best position and the best position of each bacterium. During the chemo taxis loop tumble direction is updated by:

$\varphi(j+1)=\omega * \varphi(j)+C_{1} *$ rand $*($ pbest - pcurrent $)+c_{2} *$ rand $*($ gbest - pcurrent $)$

Where pbest is the best position of each bacterium and gbest is the global best bacterium.

Chemo taxis is a foraging strategy that implements a type of local optimization where the bacteria try to climb up the nutrient concentration, avoid noxious substance and search for ways out of neutral media. A chemo tactic step size varying as the function of the current fitness value is expected to provide better convergence behaviour as compared to a fixed step size. A simple adaption scheme for the step size for $\mathrm{i}_{\text {th }}$ bacterium given in following equation

$C(i)=\frac{\left|j^{i}(\theta)\right|}{\left|j^{i}(\theta)+\Psi\right|}=\frac{1}{1+\frac{\Psi}{j^{i}(\theta)}}$

Where $\Psi$ is positive constant, $j^{i} \theta=$ cost function of the ith bacterium, $\mathrm{C}(\mathrm{i})=$ variable run (step) length of $i_{\text {th }}$ bacterium.

If $j^{i} \theta$ tends to zero then $C(i) \rightarrow 0$ and when $j^{i} \theta \rightarrow$ large, $C(i) \rightarrow 0$. This implies that the bacterium which is in the vicinity of noxious substance associates with higher cost function. Hence it takes larger steps to migrate to a place with higher nutrient concentration. Use of Eqn (20) in Eqn (17) is expected to give improved convergence performance compared to fixed step size due to the above phenomenon.

Step 1 Initialize the parameters $\mathrm{p}, \mathrm{S}, \mathrm{N}_{\mathrm{c}}, \mathrm{N}_{\mathrm{s}}, \mathrm{N}_{\mathrm{re}}, \mathrm{N}_{\mathrm{ed}}, \mathrm{p}_{\mathrm{ed}}, \mathrm{C}(\mathrm{i})(\mathrm{i}=1,2,3, . ., \mathrm{S}) \theta^{i}$

Where

$\mathrm{p}$-Dimension of the search space;

$\mathrm{S}$-Number of bacteria in the population;

$\mathrm{N}_{\mathrm{s}}$-Swimming length after which tumbling of bacteria will be undertaken in chemotactic loop;

$\mathrm{N}_{\mathrm{c}}$-The number of iterations to be undertaken in chemotactic loop, always Nc > Ns;

$\mathrm{N}_{\mathrm{re}}$-Maximum no. of reproduction steps;

$\mathrm{N}_{\mathrm{ed}}$-the maximum no. of Elimination and dispersal events to be imposed over bacteria;

$\mathrm{p}_{\mathrm{ed}}$-Probability with which elimination and dispersal will continue;

$\theta^{i}$-Location of the $\mathrm{i}^{\text {th }}(\mathrm{i}=1,2,3, . ., \mathrm{S})$ bacterium;

$\mathrm{C}(\mathrm{i})$-Step size of the $\mathrm{i}^{\text {th }}$ bacterium taken in random direction, specified by tumble. Generate a random vector $\varphi(j)$ in the range $[-11] \mathrm{C}_{1}, \mathrm{C}_{2}, \omega$ : PSO parameters

Step 2 Elimination and dispersal loop: $1=1+1$

Step 3 Reproduction loop: $\mathrm{k}=\mathrm{k}+1$

Step 4 Chemo taxis loop: $\mathrm{j}=\mathrm{j}+1$ : While updating location in Eqn (17) the adaptive run length unit, C(i) defined in Eqn (20) is used instead of fixed run length unit.

Step 5 If $\mathrm{j}<\mathrm{Nc}$, go to [Step 4]. In this case, continue chemo taxis since the life of the bacteria is not over.

Step 6 Reproduction 
Step7 If $\mathrm{k}<\mathrm{N}_{\mathrm{re}}$, go to the [Step 3]. Since in this case the specified reproduction steps are not reached, start the next generation of the chemo tactic loop.

Step8 Elimination-dispersal: For $\mathrm{i}=1,2, . ., \mathrm{S}$ with the probability $\mathrm{p}_{\mathrm{ed}}$, eliminate and disperse each bacterium, which results in keeping number of bacteria in the population constant. To do this, if a bacterium is eliminated, simply disperse one to a random location on the optimization domain. If $1<\mathrm{N}_{\text {ed }}$ then go to [Step 2], otherwise end;

\section{Simulation Results}

At first Enhanced Acclimatized Bacterial Exploration (EBE) algorithm has been tested in standard IEEE 118-bus test system [14]. The system has 54 generator buses, 64 load buses, 186 branches and 9 of them are with the tap setting transformers. The limits of voltage on generator buses are $0.95-1.1$ per-unit., and on load buses are $0.95-1.05$ per-unit. The limit of transformer rate is $0.9-1.1$, with the changes step of 0.025 . The limitations of reactive power source are listed in Table 1, with the change in step of 0.01 .

Table 1: Limitation of reactive power sources

\begin{tabular}{|l|l|l|l|l|l|l|l|}
\hline BUS & 5 & 34 & 37 & 44 & 45 & 46 & 48 \\
\hline QCMAX & 0 & 14 & 0 & 10 & 10 & 10 & 15 \\
\hline QCMIN & -40 & 0 & -25 & 0 & 0 & 0 & 0 \\
\hline BUS & 74 & 79 & 82 & 83 & 105 & 107 & 110 \\
\hline QCMAX & 12 & 20 & 20 & 10 & 20 & 6 & 6 \\
\hline QCMIN & 0 & 0 & 0 & 0 & 0 & 0 & 0 \\
\hline
\end{tabular}

The statistical comparison results of 50 trial runs have been list in Table 2 and the results clearly show the better performance of proposed Enhanced Acclimatized Bacterial Exploration (EBE) algorithm.

Table 2: Comparison results

\begin{tabular}{|l|l|l|l|l|}
\hline Active power loss (p.u) & $\begin{array}{l}\text { BBO } \\
{[\mathbf{1 5}]}\end{array}$ & $\begin{array}{l}\text { ILSBBO/ } \\
\text { strategy1 } \\
{[\mathbf{1 5}]}\end{array}$ & $\begin{array}{l}\text { ILSBBO/ } \\
\text { strategy1 } \\
{[\mathbf{1 5}]}\end{array}$ & $\begin{array}{l}\text { Proposed } \\
\text { EBE }\end{array}$ \\
\hline Min & 128.77 & 126.98 & 124.78 & 115.94 \\
\hline Max & 132.64 & 137.34 & 132.39 & 119.36 \\
\hline Average & 130.21 & 130.37 & 129.22 & 116.28 \\
\hline
\end{tabular}

Then the Enhanced Acclimatized Bacterial Exploration (EBE) algorithm has been tested in practical 191 test system and the following results have been obtained. In Practical 191 test bus system - Number of Generators $=20$, Number of lines $=200$, Number of buses $=191$ Number of transmission lines $=55$. Table 3 shows the optimal control values of practical 191 test system obtained by EBE method. And table 4 shows the results about the value of the real power loss by obtained by Enhanced Acclimatized Bacterial Exploration (EBE) algorithm. 
Table 3: Optimal Control values of Practical 191 utility (Indian) system by EBE method

\begin{tabular}{|c|c|c|c|}
\hline VG1 & 1.10 & VG 11 & 0.90 \\
\hline VG 2 & 0.72 & VG 12 & 1.00 \\
\hline VG 3 & 1.01 & VG 13 & 1.00 \\
\hline VG 4 & 1.01 & VG 14 & 0.90 \\
\hline VG 5 & 1.10 & VG 15 & 1.00 \\
\hline VG 6 & 1.10 & VG 16 & 1.00 \\
\hline VG 7 & 1.10 & VG 17 & 0.90 \\
\hline VG 8 & 1.01 & VG 18 & 1.00 \\
\hline VG 9 & 1.10 & VG 19 & 1.10 \\
\hline VG 10 & 1.01 & VG 20 & 1.10 \\
\hline
\end{tabular}

\begin{tabular}{|c|c|c|c|c|c|}
\hline $\mathrm{T} 1$ & 1.00 & $\mathrm{~T} 21$ & 0.90 & $\mathrm{~T} 41$ & 0.90 \\
\hline $\mathrm{T} 2$ & 1.00 & T22 & 0.90 & $\mathrm{~T} 42$ & 0.90 \\
\hline T3 & 1.00 & $\mathrm{~T} 23$ & 0.90 & $\mathrm{~T} 43$ & 0.91 \\
\hline T4 & 1.10 & T24 & 0.90 & T44 & 0.91 \\
\hline $\mathrm{T} 5$ & 1.00 & $\mathrm{~T} 25$ & 0.90 & $\mathrm{~T} 45$ & 0.91 \\
\hline T6 & 1.00 & T26 & 1.00 & T46 & 0.90 \\
\hline $\mathrm{T} 7$ & 1.00 & T27 & 0.90 & T47 & 0.91 \\
\hline $\mathrm{T} 8$ & 1.01 & T28 & 0.90 & T48 & 1.00 \\
\hline T9 & 1.00 & T29 & 1.01 & T49 & 0.90 \\
\hline $\mathrm{T} 10$ & 1.00 & T30 & 0.90 & T50 & 0.90 \\
\hline $\mathrm{T} 11$ & 0.90 & T31 & 0.90 & T51 & 0.90 \\
\hline $\mathrm{T} 12$ & 1.00 & T32 & 0.90 & T52 & 0.90 \\
\hline $\mathrm{T} 13$ & 1.01 & T33 & 1.01 & T53 & 1.00 \\
\hline $\mathrm{T} 14$ & 1.01 & T34 & 0.90 & T54 & 0.90 \\
\hline $\mathrm{T} 15$ & 1.01 & T35 & 0.90 & T55 & 0.90 \\
\hline T19 & 1.02 & T39 & 0.90 & & \\
\hline T20 & 1.01 & T40 & 0.90 & & \\
\hline
\end{tabular}

Table 4: Optimum real power loss values obtained for practical 191 utility (Indian) system by EBE method

\begin{tabular}{|l|l|}
\hline Real power Loss (MW) & EBE \\
\hline Min & 143.192 \\
\hline Max & 147.184 \\
\hline Average & 144.126 \\
\hline
\end{tabular}

\section{Conclusion}

Proposed Enhanced Acclimatized Bacterial Exploration (EBE) algorithm has been successfully solved reactive power problem. Enhanced Acclimatized Bacterial Exploration (EBE) algorithm is applied to obtain the optimal control variables so as to minimize the real power loss the system. The proposed Enhanced Acclimatized Bacterial Exploration (EBE) algorithm has been tested in standard IEEE 118 \& practical 191 bus test systems. And the results were compared with other standard algorithms. Simulation study make known about the most excellent 
performance of the proposed algorithm in dropping the real power loss and voltage profiles are well within the limits.

\section{References}

[1] O.Alsac, and B. Scott, "Optimal load flow with steady state security", IEEE Transaction. PAS 1973, pp. 745-751.

[2] Lee K Y ,Paru Y M , Oritz J L -A united approach to optimal real and reactive power dispatch , IEEE Transactions on power Apparatus and systems 1985: PAS-104 : 1147-1153

[3] A.Monticelli, M .V.F Pereira ,and S. Granville , "Security constrained optimal power flow with post contingency corrective rescheduling", IEEE Transactions on Power Systems :PWRS-2, No. 1, pp.175-182., 1987.

[4] Deeb N, Shahidehpur S.M, Linear reactive power optimization in a large power network using the decomposition approach. IEEE Transactions on power system 1990: 5(2) : 428-435

[5] E. Hobson ,'Network consrained reactive power control using linear programming, ' IEEE Transactions on power systems PAS -99 (4) ,pp 868-877, 1980

[6] K.Y Lee, Y.M Park, and J.L Oritz, "Fuel -cost optimization for both real and reactive power dispatches", IEE Proc; 131C,(3), pp.85-93.

[7] M.K. Mangoli, and K.Y. Lee, "Optimal real and reactive power control using linear programming”, Electr.Power Syst.Res, Vol.26, pp.1-10,1993.

[8] K.Anburaja, "Optimal power flow using refined genetic algorithm", Electr.Power Compon.Syst, Vol. 30, 1055-1063, 2002.

[9] D. Devaraj, and B. Yeganarayana, "Genetic algorithm based optimal power flow for security enhancement", IEE proc-Generation.Transmission and. Distribution; 152, 6 November 2005.

[10] C.A. Canizares, A.C.Z.de Souza and V.H. Quintana, "Comparison of performance indices for detection of proximity to voltage collapse," vol. 11. no.3, pp.1441-1450, Aug 1996.

[11] Passino, K.M., 2002. Bio mimicry of bacterial foraging for distributed optimization and control. IEEE Control Systems Magazine, pp. 52-67.

[12] Karoni, W., 2008. Bacterial foraging oriented by particle swarm optimization strategy for PID tuning. In GECCO 2008: Proceedings of the Genetic and Evolutionary computation conf, pp. 1823-1826, ACM.

[13] Dasgupta, S., Das, S., Abraham, A., Biswas, A., 2009. Adaptive Computational Chemotaxis in Bacterial Forgaing Optimization: An Analysis. IEEE Trans on Evolutionary Comp., vol. 13, pp. 919-941.

[14] IEEE, "The IEEE 30-bus test system and the IEEE 118-test system", (1993), http://www.ee.washington.edu/trsearch/pstca/.

[15] Jiangtao Cao, Fuli Wang and Ping Li, "An Improved Biogeography-based Optimization Algorithm for Optimal Reactive Power Flow", International Journal of Control and Automation Vol.7, No.3 (2014), pp.161-176.

*Corresponding author.

E-mail address: gklenin@ gmail.com 